\title{
KAJIAN PSIKOANALISIS PADA KARAKTER HEROINE DI FILM ZACK SNYDER'S JUSTICE LEAGUE (2021)
}

\author{
Daniar Wikan Setyanto' ${ }^{1}$, Santosa Soewarlan², Sumbo Tinarbuko ${ }^{3}$ \\ ${ }^{1,2}$ Pasca Sarjana Institut Seni Indonesia, Surakarta \\ ${ }^{3}$ Desain Komunikasi Visual, Institut Seni Indonesia, Yogyakarta \\ daniarwikan@dsn.dinus.ac.id ${ }^{1}$, santosa@isi-ska.ac.id ${ }^{2}$, sumbotinarbuko@gmail.com ${ }^{3}$
}

\begin{abstract}
Abstrak
Film Zack Snyder's Justice League (2021) adalah salah satu film yang meraih kesuksesan secara kritik maupun finasial di saat pandemi Covid-19. Film tersebut dianggap sebagai versi yang lebih orisinil daripada film Justice League versi layar lebar yang tayang di tahun 2017, karena merupakan film yang awalnya dikembangkan untuk berkaitan langsung dengan semesta filmfilm di DC Extended Universe (DCEU). Penelitian ini akan memfokuskan pada karakter superhero perempuan (heroine) yang muncul di film Zack Snyder's Justice League (2021) dengan menggunakan teori psikoanalisis Sigmund Freud. Tokoh heroine yang akan dikaji adalah Wonder Woman/Diana Prince, Mera dan Queen Hippolyta. Psikoanalisis dipilih karena berkaitan dengan kajian mengenai alam bawah sadar manusia seperti emosi, cinta, serta seks yang selalu muncul dalam setiap representasi karakter dalam film. Tujuan penelitian ini adalah menjelaskan serta memaknai secara komprehensif apa saja rumusan konseptual mengenai representasi perempuan dalam karakter heroine di film tersebut menurut konteks teori psikoanalisis. Manfaat penelitian ini diharapkan yaitu memberikan kontribusi pemikiran tentang penerapkan operasional teoretis dari psikoanalisis terhadap obyek penelitian budaya populer seperti karakter heroine dalam film. Penelitian ini menggunakan metode yang disebut dengan analisis konten yaitu teknik analisis mendalam terhadap isi suatu informasi dari teks maupun visual. Penelitian ini menemukan adanya keterkaitan representasi perempuan dalam karakter heroine dengan teori psikoanalisis.
\end{abstract}

Kata Kunci: heroine, film, Justice League, psikoanalisis, representasi

\begin{abstract}
In 2021 the world's film industry slumped due to the Covid-19 pandemic, Zack Snyder's Justice League (2021) movie appeared and was successful critically and commercially. The film is considered to be a more original version than the 2017 feature film Justice League because Zack Snyder's Justice League (2021) is a film that was originally developed to be directly related to the universe of films in the DC Extended Universe (DCEU). This study will focus on the female superhero character (heroines) who appears in the film Zack Snyder's Justice League (2021) and using Sigmund Freud's psychoanalytic theory. The heroine figures that studied are Wonder Woman/Diana Prince, Mera, and Queen Hippolyta. Psychoanalysis was chosen because it relates to the study of the human subconscious like emotions, love, and sex that always appear in every character representation in the film. The purpose of this study is to explain and interpret comprehensively the conceptual formulations, regarding the representation of women in heroine characters in the film Zack Snyder's Justice League (2021) according to the context of psychoanalytic theory. The benefit of this research is expected to contribute ideas about applying the theoretical operational of psychoanalysis to popular culture research objects such as heroine characters in films. This study uses a content analysis method, an in-depth analysis technique toward the content of information from text and visuals. This study found a link between the representation of women in heroine characters and psychoanalytic theory.
\end{abstract}

Keywords: film studies, heroine, Justice League, psychoanalysis, representation 


\section{PENDAHULUAN}

Tahun 2021 di saat dunia perfilman dunia masih terpuruk karena pandemi Covid-19, film Zack Snyder's Justice League (2021) berhasil menoreh kesuksesan baik secara kritik maupun finansial. HBO Max mencatat Zack Snyder's Justice League (2021) telah ditonton oleh 1.8 juta pengguna hanya dalam 4 hari. Film tersebut bahkan mendapatkan 94\% audience score di situs Rotten Tomatoes serta 8.2 di IMDB, sebuah skor yang relatif tinggi untuk sebuah film superhero. Film Zack Snyder's Justice League (2021) adalah film buatan sutradara asli dari film Justice League (2017) versi layar lebar setelah Zack Snyder mengundurkan diri karena ada perselisihan visi kreatif dengan Warner Bros selaku rumah produksi serta adanya kematian dari putrinya yang bernama Autumn Snyder yang bunuh diri pada saat produksi film Justice League (2017) belum rampung. Film Justice League (2017) akhirnya diserahkan kepada Joss Whedon yang sebelumnya menggarap film 2 film Avengers dari MCU. Namun sayangnya film Justice League (2017) versi Joss Whedon kurang mendapatkan respon positif dari penonton dan kritikus karena dianggap memiliki banyak lubang dari sisi cerita serta penokohan. Respon negatif tersebut membangkitkan gerakan dari fans DC di seluruh dunia dengan sebuah kampanye bertajuk \#ReleaseTheSnyderCut di berbagai media sosial. \#ReleaseTheSnyderCut di Twitter bahkan telah mencapai 750rb cuitan.

Pada pertengahan 2020 kabar baikpun muncul dari Warner Bros yang secara resmi mengumumkan bahwa film Zack Snyder's Justice League akan rilis di tahun 2021. Zack Snyder's Justice League (2021) memiliki plot yang hampir sama dengan versi Justice League (2017) namun versi Zack Snyder memiliki durasi yang lebih panjang yaitu mencapai empat jam. Dengan durasi selama itu tentunya memberi ruang bagi Zack Snyder untuk memberikan detail dalam cerita maupun pengembangan karakter. Secara garis besar cerita Zack Snyder's Justice League (2021) mirip dengan versi Joss Whedon yaitu tentang bersatunya pahlawan super dari DC dalam melawan serbuan alien yang bernama Steppenwolf dan para pasukannya. Anggota pahlawan super tersebut disebut dengan Justice League yang beranggotakan Superman, Batman, Aquaman, Cyborg dan Wonder Woman. Film Zack Snyder's Justice League (2021) juga dianggap sebagai versi yang lebih orisinil daripada film Justice League (2017), karena Zack Snyder's Justice League (2021) merupakan film yang awalnya dikembangkan untuk berkaitan langsung dengan semesta film DC Extended Universe (DCEU) sebelumnya seperti Man of Steel (2013) dan Batman V Superman (2016) yang juga dibuat oleh Zack Snyder.

Penelitian ini akan memfokuskan pada karakter superhero perempuan (heroine) yang muncul di film Zack Snyder's Justice League (2021). Tokoh heroine tersebut adalah Wonder Woman/Diana Prince, Mera dan Queen Hippolyta. Tokoh-tokoh tersebut dipilih karena mereka memiliki peran penting dalam plot film, semua karakter tersebut ikut ambil bagian dalam mengalahkan Steppenwolf. Fokus ini diperlukan karena penelitian ini mencoba melihat representasi karakter heroine dari sudut pandang psikoanalisis. Penggambaran heroine sebagai sosok perempuan berkekuatan super tentunya dekat dengan feminisme, sedangkan feminisme dan psikoanalisis sebenarnya memiliki beberapa kesamaan, oleh karena itulah muncul sebuah aliran feminisme psikoanalisis yang berangkat dari teori psikoanalisis (Tong, 2009). 
Psikoanalisis juga memiliki kontribusi yang besar terhadap munculnya kajian gender karena studi gender umumnya memiliki basis psikoanalisis yang sangat kuat karena selalu bersinggungan dengan studi insentif mengenai unsur psikologis gender berkaitan dengan emosi, cinta, kecemasan serta seks (Sobur, 2003). Dalam konteks gender, psikoanalis percaya bahwa penjelasan fundamental dari cara bertingkahlaku perempuan berakar dari cara berpikirnya, sedangkan cara berpikir salah satunya diperoleh dari apa yang dilihat sehari-hari termasuk dari film. oleh karena itulah pendekatan psikoanalisis dianggap tepat untuk menganalisis fenomena heroine. Psikoanalisis juga merupakan sebuah disiplin ilmu yang secara ekstensif mempelajari "mimpi" (dream) sebagai kunci untuk bagian tidak sadar diri manusia (the unconscious) dan efek cermin psikologis pada pembentukan identitas subyek (Ali, 2009). Dalam konteks kajian film dan seni secara umum psikoanalisis juga dapat digunakan untuk menjelaskan proses menonton, membaca dan memaknai representasi identitas yang ada pada karakter film.

Perlu diketahui bahwa film ini telah dilihat oleh jutaan masyarakat yang di seluruh dunia, segmentasi dari film superhero modern bukan hanya anak-anak namun juga untuk dewasa sehingga menggambaran karakter heroine dalam film Zack Snyder's Justice League (2021) tentunya dipengaruhi juga dari sudut pandang orang dewasa, karena karakter heroine adalah obyek visual yang dapat meningkatkan hasrat (desire). Sebagai sosok imaginer, karakter heroine memiliki referensi visual secara fisik dan biologis sehingga dapat merangsang macam-macam hasrat yang ada dalam diri manusia seperti rasa suka, benci bahkan dorongan seksual/libido (Setyanto, Soewarlan and Tinarbuko, 2019). Akan tetapi setiap hasrat yang muncul tidak dihasilkan lewat bentuk fisik yang nyata hanya berupa visualisasi yang muncul pada layar maka kepuasan tersebut hanya berhenti pada kepuasan yang bersifat tidak nyata (fantasi). Kepuasan tidak nyata/fantasi inilah yang dibahas dalam teori psikoanalisis Sigmund Freud. Menurut Freud manusia merupakan makhluk biologis/fisik dan psikis maka manusia memiliki kemampuan menciptakan hasratnya sendiri. Hasrat tersebut diciptakan dan disalurkan lewat berbagai macam ekspresi seni contohnya gambar/lukisan dan film. Hasrat tersebut selalu mencari penyaluran berupa kepuasan yang bersumber dari tubuh. Proses penyaluran kepuasan terhadap hasrat ikut membantu pembentukan visualisasi dan penokohan karakter heroine. Sehingga karakter heroine tidak bisa dilepaskan dari unsur daya tarik seksual, kekuatan, pengaruh dan kharisma pada sosok perempuan ideal (Jeffrey A. Brown, 2011). Alur psikoanalisis dalam penelitian ini diawali dengan adanya asumsi bahwa karakter heroine (sebagai obyek penelitian) merupakan permainan tanda yang muncul dari hasrat yang terpendam dari pencipta (kreator film) dan para penonton, sehingga dengan melihat para karakter heroine dalam film, alam bawah sadar penonton ikut mengkonsumsi simbol-simbol libidinal yang ada dalam layar film.

Rumusan masalah penelitian ini adalah bagaimana representasi identitas perempuan pada tokoh-tokoh heroine di film Zack Snyder's Justice League (2021) menurut konteks psikoanalisis Sigmund Freud. Tujuan penelitian ini adalah menjelaskan serta memaknai secara komprehensif apa saja rumusan konseptual mengenai representasi perempuan pada karakter heroine di film Zack Snyder's Justice League (2021) menurut konteks teori 
psikoanalisis Sigmund Freud. Sedangkan manfaat penelitian ini adalah memberikan kontribusi pemikiran terhadap penerapkan operasional teoretis dari psikoanalisis terhadap karakter heroine dalam film Zack Snyder's Justice League (2021).

\section{METODE PENELITIAN}

Metodologi penelitian yang digunakan adalah metodologi kajian antardisiplin, sebuah metodologi kajian yang menggunakan lebih dari satu disiplin ilmu sesuai dengan rekomendasi Barker untuk penelitian yang memiliki basis kajian budaya (Barker, 2003). Menurut Sumbo Tinarbuko dalam ceramah ISICA\#2 2019 yang diselenggarakan di ISI Surakarta, penelitian yang berkaitan dengan budaya visual termasuk film akan lebih baik jika menggunakan lintas bidang ilmu karena akan memberi keragaman dalam hal sudut pandang (Tinarbuko, 2019). Oleh karena itulah penelitian ini menggunakan psikoanalisis sebagai teori untuk mengkaji representasi dari karakter heroine. Penggunaan teori psikoanalisis diharapkan bisa memberikan sudut pandang baru dalam kajian film sehingga hasil yang didapat dari penelitian ini akan memberikan kebaharuan bagi penelitian yang berbasis pada kajian film, identitas dan feminisme.

Penelitian ini menggunakan metode analisis konten. Menurut Harold D. Lasswell analisis konten adalah penelitian yang bersifat pembahasan mendalam terhadap isi suatu informasi yang muncul dalam media massa. Hasil dari analisa atau kajian yang digunakan dalam analisis konten berupa kesimpulan yang bersifat deskriptif sehingga dapat diulang dari data yang berkaitan dengan konteksnya. Metode ini biasa digunakan untuk meneliti media (Janowitz, 1968). Dalam penelitian budaya populer analisis konten digunakan karena dapat bersentuhan langsung dengan teks dan gambar. Dalam kajian film, analisis konten menggunakan dialog (teks) dan adegan (gambar) yang ada dalam film untuk mendukung kajian yang bersifat kualitatif (Rose, 2016). Aplikasi sederhana dari metode analisis konten dalam penelitian ini yaitu dengan mengamati langsung setiap adegan yang ada di film, kemudian memilah-milah mana saja adegan yang berkaitan dengan elemen kepribadian dalam teori psikoanalisis, setelah itu memberikan deskripsi secara kualitatif dari adegan-adegan tersebut.

\section{HASIL DAN PEMBAHASAN}

\subsection{Sekilas tentang Psikoanalisis Sigmud Freud}

Psikoanalisis adalah cabang ilmu yang ditemukan pertama kali oleh Sigmund Freud lalu dikembangkan oleh pengikutnya, sebagai ilmu yang mempelajari fungsi dan perilaku psikis dari manusia. Psikoanalisis berasal dari ide-ide Sigmund Freud khususnya mengenai mimpi (dream) telah menjadi dasar untuk terapi modern serta menjadi salah satu aliran psikologi terbesar saat ini (Bertens, 2006). Pemikiran Freud tentang perilaku manusia berdasarkan dari pengalamannya dengan pasien serta pengetahuan literatur yang luas terhadap ilmu pengetahuan dan kemanusiaan. Pengalaman dari Freud selama puluhan tahun merupakan data yang menjadi dasar evolusi psikoanalis. Bahkan sampai saat ini teori psikoanalisis terus dikembangkan oleh para pengikutnya dan mengalami revisi dan pengembangan meski sudah lebih dari 50 tahun sejak teori ini muncul (Helaluddin, 2018). 
Menurut Teori Psikoanalisis Freud, perilaku manusia dipengaruhi oleh kondisi psikologis yang tidak terlihat. Oleh Freud kondisi psikis yang tidak tampak tersebut dibagi menjadi tiga struktur, yaitu 1) Struktur alam sadar (conscious) merupakan struktur yang berisi semua hal yang pernah dicermati pada saat tertentu namun hanya bagian kecil dari kehidupan mental. Contohnya ingatan (memory), persepsi (perception), perasaan (feeling), dan pikiran (mind). Semua proses yang terjadi pada alam sadar adalah hasil dari penyaringan yang diatur oleh stimulus dan hanya berlangsung singkat. 2) Struktur prasadar (preconscious) sering juga disebut dengan istilah "ingatan siap" (available memory). Memiliki fungsi jembatan antara alam sadar dan tak sadar. Bentuk yang sering terjadi terjadi dari stuktur prasadar adalah mimpi, salah ucap serta gerak reflek dalam mekanisme fisik. Dan 3) Struktur tidak sadar (unconscious) adalah struktur paling dalam psikis manusia yang isinya berupa naluri (insting), hasrat (desire), dorongan yang alami yang ada pada manusia sejak bayi, serta pengalaman yang bersifat traumatik. Setiap unsur yang ada pada struktur ini bisa berlangsung lama dan memiliki potensi dalam mempengaruhi perilaku manusia.

Selain membagi struktur psikis ke dalam tiga tingkatan, psikoanalisis membagi dinamika psikis manusia menjadi tiga komponen kepribadian yang saling berhubungan. Sama halnya dengan struktur psikis, tiga komponen ini juga mempengaruhi perilaku manusia baik dalam bertindak maupun mengambil keputusan (Lapsley and Stey, 2011). Ketiga komponen kepribadian tersebut adalah pertama, Super Ego (Das Uber-Ich) merupakan energi psikis yang berisi nilai/kaidah moral, rambu-rambu, norma yang diyakini oleh individu dari lingkungan. Super ego seringkali berlawanan dengan id dan berfungsi sebagai tembok pembatas supaya manusia tidak bertindak liar seperti binatang. Super ego secara sederhana bisa diartikan sebagai hal-hal baik/positif yang diserap oleh alam bawah sadar. Kedua, Ego (Das Ich) merupakan pengawas realita atau komponen kepribadian yang bertugas mengikuti prinsip realita (realityprinciple). Ego juga diartikan sebagai sisi rasional dari manusia yang berisi pertimbangan-pertimbangan yg akan ditempuh saat id dan super ego mengalami kesenjangan. Terakhir, ketiga, Id (Das Es) merupakan komponen kepribadian yang berisi energi psikis yang beorientasi pada kesenangan semata. Id juga seringkali dihubungkan kepada hal-hal yang bersifat negatif karena berkaitan langsung dengan nafsu atau kesenangan dan kepuasan sejarah jasmani. Dalam psikoanalisis kesenangan ini dibagi dua kategori yaitu bersifat sexual (eros) dan kuasa/power (thanatos).

Tingkat kesadaran psikis dan komponen kepribadian manusia menurut psikoanalisis bisa digambarkan sebagai fenomena gunung es (iceberg). Artinya segala sesuatu dari perilaku yang nampak dari manusia hanyalah bagian kecil dari struktur kesadaran. Dan yang tidak nampak dan lebih banyak mempengaruhi perilaku justru ada seringkali sulit diamati karena ada pada struktur alam tak sadar (unconscious). Atau dalam kata lain yang seringkali nampak dan mudah diamati adalah alam sadar (conscious) berada di puncak namun memiliki porsi yang kecil, sedangkan yang ada di tengah adalah alam pra sadar (preconscious), namun yang paling banyak mempengaruhi perilaku adalah justru alam tidak sadar (unconscious) yang ada dibawah permukaan air. Sedangkan untuk komponen kepribadian yang nampak dan mudah diamati adalah komponen Ego dan 
super ego. Untuk komponen kepribadian berupa id merupakan unsur paling kompleks sekaligus paling berpengaruh dalam kepribadian manusia karena berada sepenuhnya dalam alam bawah sadar.

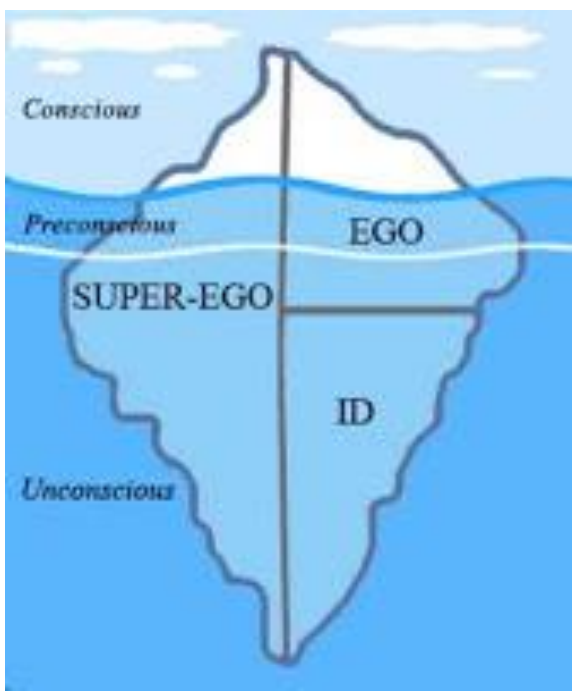

Gambar 1. Fenomena Gunung Es dari Tingkat Kesadaran Psikis dan Komponen Kepribadian Menurut Psikoanalisis

[Sumber: Psikoanalisis Sigmud Freud]

Kaitannya dengan penelitian ini, karakter heroine dalam film Zack Snyder's Justice League (2021) yaitu karakter Wonder Woman, Mera, dan Queen Hippolyta akan dikaji dengan terminologi psikoanalisis yang berfokus teori alam bawah sadar (unconscious), serta tiga komponen kepribadian yaitu Id, ego dan super ego karena memahami aspek unconscious merupakan kunci untuk memahami pembentukan identitas karakter dari sebuah film. Untuk lebih jelasnya bisa dilihat dari bagan di bawah ini

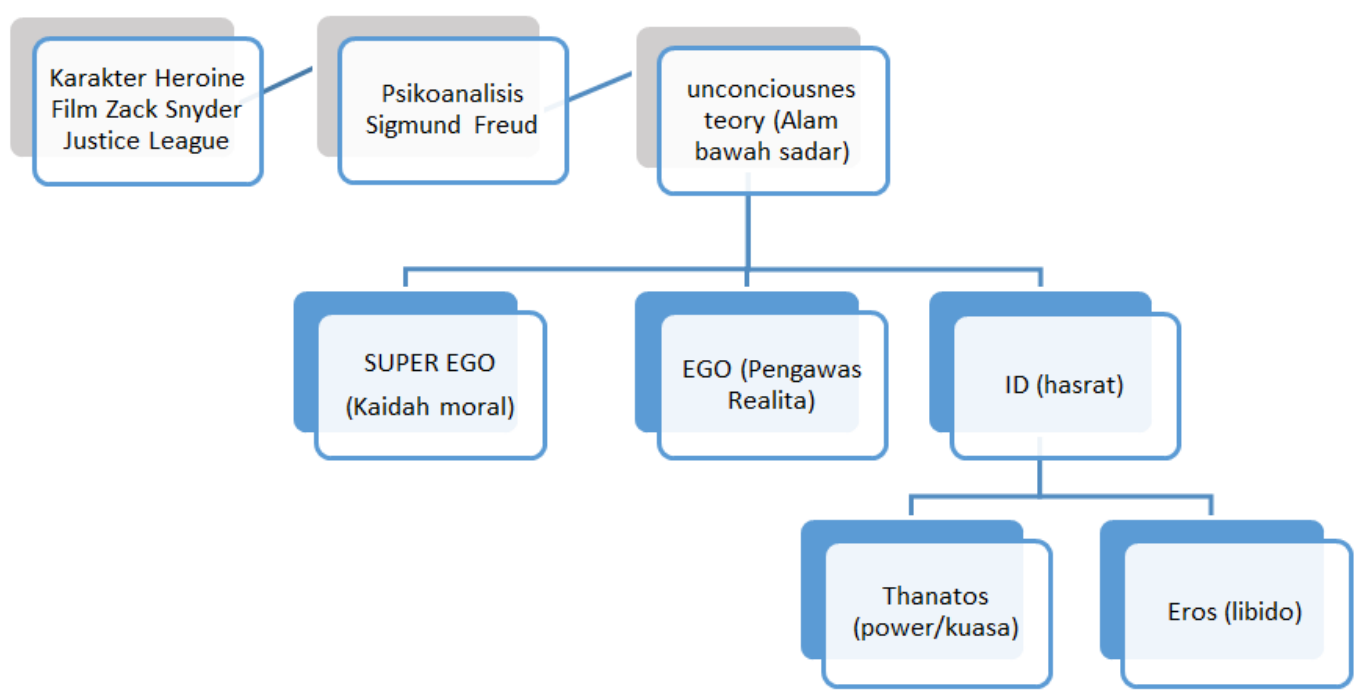

Gambar 2. Bagan Alur Penelitian

[Sumber: Dokumentasi Penulis] 


\subsection{Karakter Heroine dalam Film Zack Snyder's Justice League (2021)}

\subsubsection{Wonder Woman}

Karakter Wonder Woman atau Diana Prince pertama muncul di All Star Comics \#8 (1941). Dalam film biopik Professor Marston and the Wonder Women (2017) diceritakan bahwa pencipta karakter Wonder Woman yakni William Moultoni Marston awalnya merancang karakter tersebut dengan nama Suprema karena fantasinya akan BDSM (Bondage, Discipline, Dominance, Submission) dalam kegiatan seksual. Namun berjalannya waktu karakter Suprema akhirnya diganti menjadi Wonder Woman. Sebagai kreator William Moultoni Marston juga terinspirasi dari istrinya yaitu Elizabeth Hollowy, dan pasangan hidup mereka, Olive Byrne.

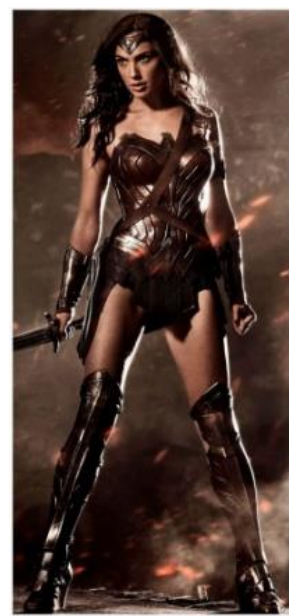

Gambar 3. Karakter Heroine DC Wonder Woman

Saat ini Karakter Wonder Woman telah bertransformasi menjadi simbol feminisme paling populer di dunia. Di film Zack Snyder's Justice League (2021) karakter tersebut diperankan oleh artis Amerika berdarah Israel bernama Gal Gadot. Dalam film tersebut Wonder Woman merupakan satu-satunya anggota perempuan dari Justice League. Beberapa senjata yang dipakai oleh Wonder Woman dalam membela diri, yaitu Tiara (mahkota yang fungsinya juga bisa menjadi senjata/bumerang), tameng, pedang (god killer), pelindung lengan yang kuat, tali pecut sakti (lasso of truth) yang selain sebagai senjata juga bisa berfungsi untuk memaksa musuh berkata jujur dan pakaian tempur (armor) yang disebut golden eagle armor yang membuat Wonder Woman bisa terbang (Misiroglu and David A, 2004).

\subsubsection{Mera}

Mera merupakan karakter heroine dari DC yang dikenal sebagai kekasih/istri dari karakter superhero Aquaman/Arthur Curry. Karakter Mera tidak memiliki alter ego, yang berarti Mera hanya memiliki profil sebagai Mera (dirinya sendiri) yaitu seorang putri dari kerajaan laut Atlantis. Hal tersebut tentunya berbeda dengan kebanyakan karakter superhero maupun heroine yang digambarkan memiliki identitas alter ego misalnya Clack Kent merupakan alter ego dari Superman atau Diana Prince alter ego dari Wonder Woman. 


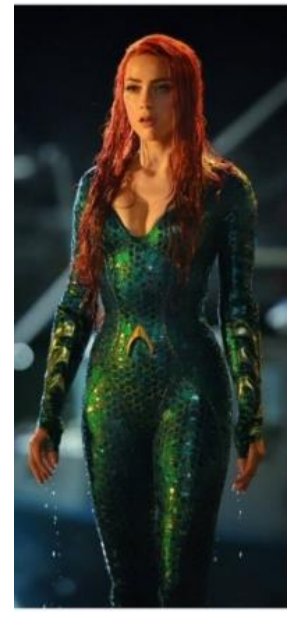

Gambar 4. Karakter Heroine DC Mera

Tokoh Mera pertama kali muncul di komik Aquaman \#11 (1963), berbeda dari versi filmnya karakter Mera dalam komik awalnya digambarkan sebagai ratu dari Dimension Aqua atau bangsa Xebel yang merupakan ras alien yang hidup di bawah laut (Misiroglu and David A, 2004). Sedangkan dalam film, karakter Mera diperankan oleh Amber Heard muncul pertama kali di film Justice League (2017). Di komik dan film, karakter Mera digambarkan sebagai wanita kuat dan perkasa yang memiliki banyak kemampuan yang bersumber dari air seperti menggerakkan air atau hidrokinesis, bernafas dalam air, berenang dengan kecepatan tinggi, kemampuan beladiri, berbicara dengan mahluk air, dII. Dalam film Zack Snyder's Justice League (2021), karakter Mera bukan anggota Justice League sehingga tidak ikut dalam pertempuran terakhir dengan Steppenwolf namun karakter ini termasuk karakter penting dalam jalinan cerita karena menjadi salah satu pelindung motherboxes yang ada di Atlantis. Karakter Mera juga memiliki andil terhadap keterlibatan Aquaman dalam Justice League, karena Mera adalah tokoh yang membujuk Aquaman sehingga mau bergabung dengan Justice League untuk melawan Steppenwolf (Rovin, 1985).

\subsubsection{Queen Hippolyta}

Ratu Hippolyta adalah tokoh fiktif asal DC yang merupakan ibu Wonder Woman/Diana Prince. Sama seperti Wonder Woman tokoh ini juga ciptaan William Moulton Marston. Pertama muncul pada tahun 1941 di All Star Comics sebagai ratu kaum Amazon. Debut film layar lebar tokoh ini diperankan oleh Connie Nielsen pertama kali muncul di film Wonder Woman (2017) yang masih satu universe dengan DCEU, Queen Hipolyta juga Kembali di sekuelnya yaitu Wonder Woman 1984 (2020). Dalam menciptakan karakter Queen Hippolyta, William Moulton Marston terinspirasi dari legenda Yunani. Dalam legenda Yunani, Hippolyta merupakan gabungan reinkarnasi jiwa dari dewi Olympian yang bernama Ertemis, Athena, Hestia, Demeter dan Aphrodite (Beatty and Jimenez, 2004). 


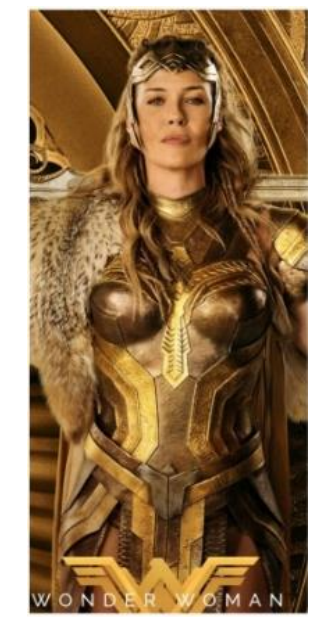

Gambar 5. Karakter Heroine DC Queen Hippolyta

Dalam film Zack Snyder's Justice League (2021) Queen Hippolyta merupakan pemimpin dari Themyscira sebuah kota fiktif yang didiami suku Amazon yaitu suatu suku yang berisi para pejuang perempuan penjaga Motherboxes. Meskipun dari segi kekuatan tidak digambarkan sekuat superhero populer seperti Superman dan Wonder Woman, karakter Queen Hippolyta juga memiliki kemampuan yang melebihi manusia biasa seperti hidup abadi/immortal, kemampuan beladiri, daya tahan serta stamina yang kuat. Sebagai seorang ratu pemimpin bangsa Amazon, Queen Hippolyta juga merupakan karakter yang cerdas, penuh kebijaksanaan, tegas namun juga memiliki hati yang lembut (Rovin, 1985).

\subsection{Analisis Komponen Kepribadian dalam Karakter Heroine}

\subsubsection{Komponen Kepribadian Super Ego (Das Uber-Ich)}

Komponen kepribadian super ego bisa dilihat dari sifat positif yang dimiliki oleh karakter heroine. Sifat baik dimiliki oleh para karekter heroine baik Wonder Woman, Mera dan Queen Hippolyta adalah sifat patriotisme atau kepahlawanan, yaitu sikap rela berkorban dan mau berjuang untuk kepentingan orang lain. Sikap patriotisme ini ditunjukkan di banyak Scene beberapa di antaranya adalah saat karakter Wonder Woman menolong orang-orang dari peristiwa perampokan, lalu scene saat Queen Hippolyta dan pasukan Amazon melindungi Motherbox dari serbuan Steppenwolf dan pasukannya. Sifat patriotisme dari karakter Mera juga ditunjukkan pada saat scene Mera melindungi Motherbox dari Steppenwolf. Sikap patriotisme sebenarnya jamak dimiliki oleh karakter protagonis film-film bertema superhero karena garis besar filmnya bertutur tentang kepahlawanan. Komponen super ego lainnya yang muncul dalam karakter heroine adalah sifat-sifat seperti rela berkorban, sifat rendah hati dan bijaksana. 


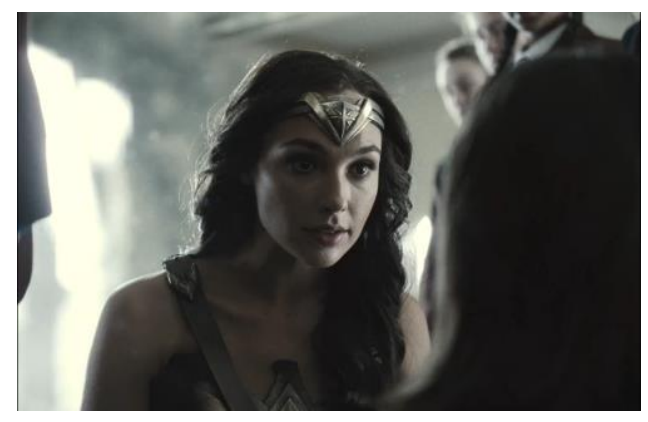

Gambar 6. Wonder Woman Berbicara pada Salah Satu Siswa ST. Brigid Setelah Menyelamatkannya dari Serangan Teroris

[Sumber: Film Zack Snyder's Justice League 00:25:04-00:25:55]

Ada satu scene yang secara eksplisit memberikan elemen moral/pelajaran terkait nilainilai yaitu pada saat adegan Wonder Woman berbicara pada salah satu siswa St. Brigit selepas Wonder Woman mengalahkan teroris yang menyandera para siswa dan guru St. Brigit. Pesan moral itu terekam dari dialog antara Wonder Woman dan siswi tersebut.

Siswi St. Brigit : "can i be like you someday ?"

Wonder Woman : "you can be anything you want to be !"

Dari dialog tersebut bisa diartikan bahwa Wonder Woman sedang memberikan pesan moral kepada audiens (yang direpresentasikan oleh siswi ST. Brigit) bahwa siapapun berhak untuk memiliki cita-cita setinggi mungkin. Pesan tersebut mengkin saja terlihat sederhana, namun apabila melihat konteks Wonder Woman sebagai heroine berkekuatan super dan siswi ST. Brigit sebagai anak kecil yang merupakan manusia biasa maka pesan tersebut menjadi penting karena pesan tersebut berisi petuah moral agar kita tidak menjadi rendah diri.

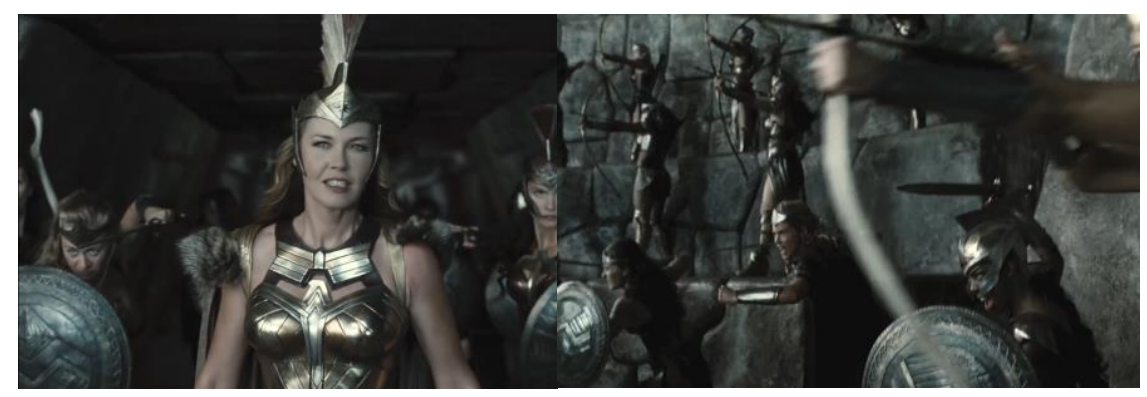

Gambar 7. Queen Hippolyta Memberi Semangat Pasukan Themyscira saat Melawan Steppenwolf [Sumber: Film Zack Snyder's Justice League 00:28:03-00:28:10]

Komponen super ego yang diperlihatkan oleh karakter heroine juga muncul pada scene di saat karakter Queen Hippolyta berteriak kepada para pasukan Themyscira. Saat itu pasukan Themyscira akan melawan villain Steppenwolf yang ingin mencuri motherbox. Di awal adegan kita akan melihat Steppenwolf mengintimidasi pasukan Themyscira dengan cara akan memberi rasa takut kepada para pasukan Themyscira. Namun kemudian sebelum menyerang Queen Hippolyta bertanya kepada para pasukan Themyscira "Doughter of Themyscira, show him yours fear !!!", para pasukan Themyscira 
menjawab dengan sangat lantang "we have no fear !!". lewat adegan tersebut, film ini mengajarkan pesan moral bahwa sebaiknya kita tidak perlu takut melawan kejahatan dan bahkan seharusnya melawan kejahatan tersebut sampai titik darah penghabisan.

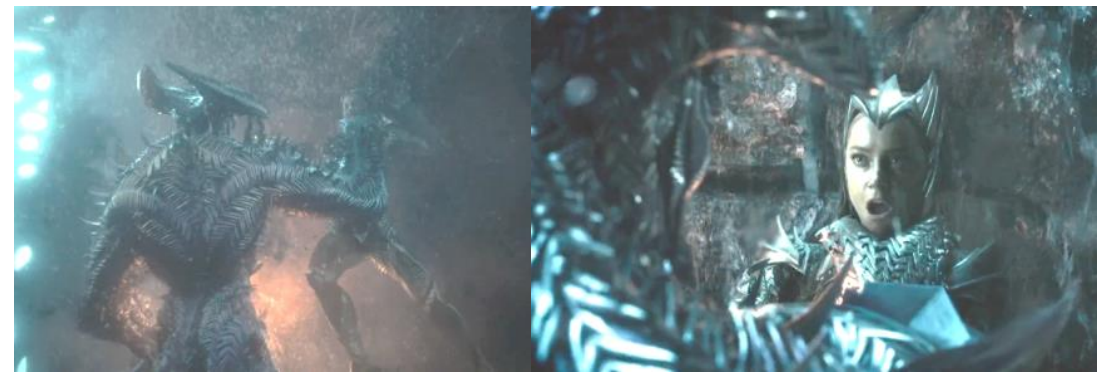

Gambar 8. Mera saat Melawan Steppenwolf

[Sumber : Film Zack Snyder's Justice League 01:46:00-01:28:30]

Nilai-nilai patriotisme juga diperlihatkan di scene ketika karakter Mera melindungi motherbox dari Steppenwolf. Diceritakan dalam adegan tersebut Mera harus melawan Steppenwolf yang jauh lebih kuat dari dirinya dan membuat Mera nyaris terbunuh apabila tidak ditolong oleh Aquaman. Dalam scene tersebut karakter mera sempat berbicara kepada Steppenwolf bahwa dia tidak akan melarikan diri dan akan menjaga motherbox meski nyawa taruhannya. Hal tersebut bisa diartikan bahwa Mera rela berkorban demi sesuatu yang jauh lebih penting yaitu keselamatan umat manusia di bumi, karena apabila semua motherbox bisa direbut oleh Steppenwolf maka hal tersebut bisa membawa kehancuran baik di bumi ataupun di Atlantis. Melalui beberapa scene di atas maka terlihat bahwa sifat patriotisme menjadi salah satu nilai moral yang paling sering diperlihatkan dalam film ini.

\subsubsection{Komponen Kepribadian Ego (Das Ich)}

Ego merupakan sisi psikologis yang berisi pertimbangan rasional, aspek ini bisanya memiliki peran penting saat menemukan kondisi realita yang tidak ideal atau tidak sesuai dengan keinginan. Sehingga merupakan komponen psikologis yang paling berperan dalam hal pengambilan keputusan.

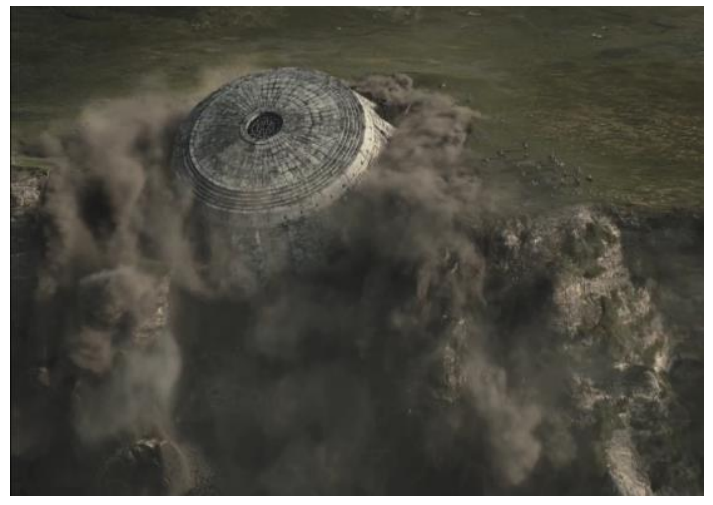

Gambar 9. Scene The Battle Of Themyscira saat Bangunan yang Berisi Steppenwolf Peserta Para Pasukan Themyscira Roboh Kemudian Jatuh ke Laut

[Sumber : Film Zack Snyder's Justice League 00:31:00-00:31:25] 
Komponen ego bisa ditemukan dalam adegan The Battle of Themyscira pada saat Queen Hippolyta akhirnya mengorbankan para pasukan Themyscira demi menyelamatkan motherbox dari tangan Steppenwolf. Bentuk pengorbanan itu yaitu dengan cara meninggalkan para pasukan Themyscira berada dalam bangunan bersama Steppenwolf dan pasukannya. Bangunan tersebut akhirnya dikunci dan dirubuhkan hingga jatuh ke dalam laut, dengan harapan Steppenwolf dan pasukannya ikut tewas di dalam bangunan tersebut. Pengambilan keputusan tersbut tentu sangat berat bagi Queen Hippolyta, hal tersebut tergambar saat adegan Queen Hippolita pergi meninggalkan bangunan dengan raut wajah sedih dan menangis. Namun keputusan tersebut dilakukan oleh Queen Hippolyta demi menyelamatkan motherbox dari Steppenwolf yang sangat kuat. Dalam scene ini akhirnya Steppenwolf tetap hidup dan berhasil merebut motherbox dari para pasukan Themyscira, dan membuat Queen Hippolyta mengambil jalan akhir yaitu meminta bantuan putrinya Diana Prince (Wonder Woman) dengan cara menghidupkan api abadi dengan panah Artemis. Lewat adegan tersebut prinsip realita (reality principle) digambarkan dengan kondisi di saat Queen Hippolyta menyadari realita bahwa dia dan pasukannya tidak mampu melawan Steppenwolf yang telalu kuat, sehingga Queen Hippolyta mengambil keputusan berat yaitu dengan mengorbankan pasukan Themyscira demi menghalau Steppenwolf.

\subsubsection{Komponen Kepribadian Id (Das Es)}

1) Bersifat Sexual (Eros)

Unsur Id yang bersifat sexual (eros) cukup jelas nampak dalam hal visualisasi karakter heroine. Semua karakter heroine yang ada pada film Zack Snyder's Justice League (2021) digambarkan memiliki wajah yang cantik serta postur yang menarik secara fisik dan seksual. Kostum yang dimiliki oleh Wonder Woman, Mera, dan Queen Hippolyta cenderung memiliki desain yang ketat dan menonjolkan bentuk tubuh. Bahkan untuk karakter Wonder Woman dan Mera desain kostum dibuat dengan cukup terbuka di bagian dada. Penampilan para artis yang memerankan karakter heroine juga tidak jauh berbeda di kehidupan nyata, artis pemeran karakter heroine tersebut yaitu Gal Gadot, Amber Heard dan Connie Nielsen semuanya memiliki rekam jejak sebagai model sehingga foto-foto seksinya cukup mudah ditemukan di internet. Hal tersebut membuktikan bahwa penampilan fisik yang yang beorientasi terhadap daya tarik fisik dan seksual menjadi salah satu unsur penting dalam visualisasi karakter heroine.

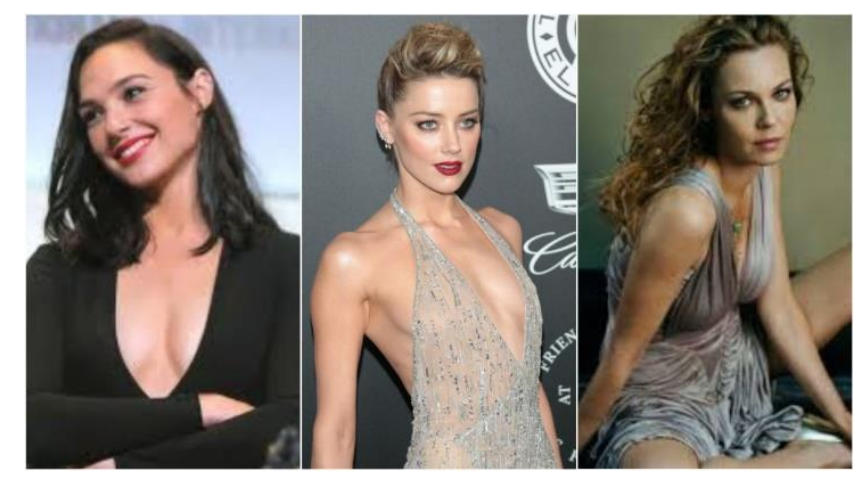

Gambar 10. Pemeran Karakter Heroine di Film Zack Snyder's Justice League (2021) dari Kiri ke Kanan; Gal Gadot, Amber Heard, dan Connie Nielsen 


\section{2) Bersifat Kekuasaan/Power (Thanatos)}

Untuk unsur Id yang bersifat kekuasaan/power (thanatos) diperlihatkan dalam bentuk kekuatan super yang ada dalam diri heroine. Unsur kekuatan super sebenarnya sudah jamak dimiliki oleh para superhero tidak terkecuali oleh heroine yang ada di film Zack Snyder's Justice League (2021). Kekuatan super yang ada dalam tiap karakter memiliki sesuatu yang khas dan berbeda satu sama lain, namun umumnya memiliki kekuatan yang jauh lebih kuat daripada manusia normal seperti kemampuan terbang pada Wonder Woman, kemampuan bernafas dalam air dan mengendalikan air pada karakter Mera, serta kemampuan berperang dan hidup abadi pada Queen Hippolyta.

Selain kekuatan fisik, unsur id yang bersifat kekuatan (thanatos) juga diperlihatkan dalam bentuk kepemimpinan, derajat/kasta dan kekayaan. Misalnya karakter Wonder Woman yang merupakan putri dari ratu kaum Amazon keturunan langsung dari Dewa Zeus, sedangkan Mera juga merupakan seorang putri dari kerajaan Atlantis (queen of Atlantis) anak dari Raja Xebel, sedangkan Queen Hippolyta merupakan pemimpin dari bangsa themiscyra yang sangat dihormati oleh rakyatnya. Penggambaran tersebut menunjukkan bahwa ketiga karakter heroine tersebut memiliki kekuasaan, derajat/kasta yang tinggi serta kekayaan yang melimpah.

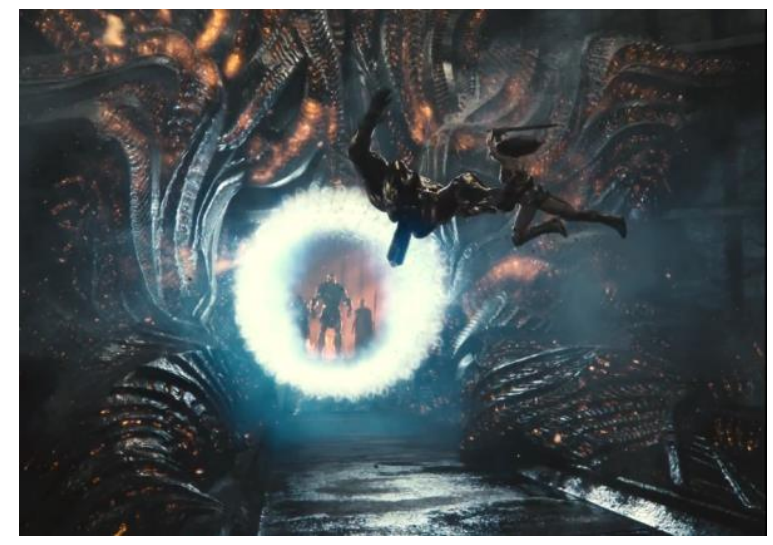

Gambar 11. Adegan Wonder Woman Memenggal Kepala Steppenwolf [Sumber : Film Zack Snyder's Justice League 03:30:10-03:30:40]

Dalam adegan penghujung Final Battle saat para anggota Justice league berhasil mengalahkan Steppenwolf. Ada satu scene yang sangat mencuri perhatian yaitu di saat Wonder Woman memenggal kepala Steppenwolf. Scene tersebut merujuk pada salah satu elemen psikologi thanatos yaitu kemarahan/dendam. Adegan ini merupakan representasi dari luapan dendam dari karakter Wonder Woman sangat marah terhadap Steppenwolf karena telah banyak membunuh para penduduk Themyscira yang merupakan tempat asal dari Wonder Woman.

Dalam konteks representasi identitas, film ini merupakan salah satu contoh di mana sosok perempuan dihadirkan dengan kuantitas mereka yang seimbang dengan pria dalam industri perfilman serta dapat memberikan peran krusial untuk meningkatkan kualitas dari film tersebut. Film ini secara cerdas memberikan kedalaman karakter heroine menjadi lebih kompleks dengan elemen-elemen psikoanalisis sehingga tidak 
semata-mata hanya mengandalkan aspek fisik dan sensualitas. Lewat karakter heroine, perempuan dalam industri film bukan sekedar tampil untuk diekspose secara fisik dan seksual namun juga memperlihatkan kualitas-kualitas lain lewat penokohannya yang kompleks. Lewat karakter heroine yang ada di film Zack Snyder's Justice League (2021) perempuan bukan sekedar sebagai pelengkap atau pemanis sebuah film (Irawan, 2017). Karakter heroine yang merupakan representasi perempuan dalam film ini digambarkan memiliki sifat yang kompetitif, individualistis, cerdas, berjiwa kepemimpinan, agresif dan aktif dengan tetap bebas bergerak di ruang privat maupun publik dalam menjalankan setiap aksinya, representasi perempuan dalam karakter heroine memiliki sifat-sifat gabungan dari feminin maupun maskulin, namun kekuatan dan kedudukannya seimbang dengan pria sehingga kehadiran perempuan tidak bergantung maupun meminggirkan peran laki-laki (Hendarto, 2017).

\section{KESIMPULAN}

Apabila dilihat dari sudut pandang psikoanalisis maka komponen kepribadian super ego (das uber-ich) yang muncul pada karakter heroine di film Zack Snyder's Justice League (2021) cenderung kepada nilai-nilai stereotip perempuan (berhati lembut, sederhana, rasa malu, sifat mendukung, empati, hati-hati, simpatik, intuitif, sensitif, dan peduli). Sedangkan nilai-nilai stereotip laki-laki yaitu patriotisme, kekerasan hati, ambisi, keberanian, kemandirian, ketegasan dan ketahanan fisik merupakan komponen kepribadian dari id (das es). Komponen ego (das ich) muncul berupa sikap rasional dan mampu mengendalikan emosi dalam setiap pengembangan karakter terutama saat pengambilan keputusan. Dalam hal ini representasi karakter heroine jelas bahwa perempuan harus tetap berpegang teguh pada femininitas namun juga menjunjung tinggi etika kepedulian (ethics of care) dan etika keadilan (ethics of justice) sehingga memberi ruang kepada sifat-sifat yang identik dengan maskulinisme masuk ke dalam diri perempuan. Namun diantara ke tiga elemen psikologis ego, super ego dan id yang paling dominan di representasikan dalam karakter heroine adalah elemen id khususnya yang berkaitan dengan power/kekuatan (thanatos) karena sepanjang film kita bisa melihat bahwa kekuatan fisik merupakan aspek paling banyak muncul karena secara garis besar film tersebut adalah film aksi dimana konklusi akhir dari sebuah konflik adalah dengan adu kekuatan.

Berdasarkan analisa komponen kepribadian psikoanalisis Freud disimpulkan bahwa representasi karakter heroine dalam film Zack Snyder's Justice League (2021) adalah bahwa perempuan saat ini mulai bergerak maju menuju masyarakat androgini, yaitu sebuah kategori identitas atau representasi yang merupakan campuran sifat positif feminin dan maskulin. Hal tersebut nampak bila dikaitkan dengan representasi karakter heroine yang muncul dalam film film Zack Snyder's Justice League (2021), sosok heroine diperlihatkan memiliki gabungan dari dua unsur paradoks antara feminim dan maskulin, atau merupakan serapan dari sifat-sifat unggul yang dimiliki oleh perempuan (feminim) dan pria (maskulin), disatu sisi tangguh, jago bertarung, kuat dan tegas yang mewakili sifat maskulin, namun juga cantik secara fisik (seksual) dan berhati lemah lembut yang mewakili sifat feminim. 


\section{DAFTAR PUSTAKA}

Ali, M. (2009). Psikologi Film : Membaca Film Lewat Psikoanalisis Lacan-Zizek. Jakarta: IKJ Retrospeksi dan Eksplorasi.

Barker, C. (2003). Cultural studies: Theory and practice. London: Sage.

Beatty, S. and Jimenez, P. (2004). The DC Comics Encyclopedia-The Definitive Guide to the Characters of the DC Universe./2004 Dorling Kindersley. New York: 2004 Dorling Kindersley.

Bertens, K. (2006). Psikoanalisis Sigmund Freud. Jakarta: Gramedia Pustaka Utama.

Helaluddin. (2018). 'Psikoanalisis Sigmund Freud dan Implikasinya dalam Pendidikan', UIN Sultan Maulana, $0 . \quad$ Available at: https://www.researchgate.net/publication/323535054_Psikoanalisis_Sigmun d_Freud_dan_Implikasinya_dalam_Pendidikan.

Hendarto, N. C. (2017). 'Representasi Posfeminisme Dalam Film Alice Through The Looking Glass', Jurnal e-Komunikasi, 5(2). Available at: http://publication.petra.ac.id/index.php/ilmu-komunikasi/article/view/7072 (Accessed: 13 June 2019).

Irawan, R. E. (2017). 'Representasi Perempuan dalam Industri Sinema', Humaniora, 5(1), pp. 1-8.

Janowitz, M. (1968). 'Harold D. Lasswell's contribution to content analysis', The Public Opinion Quarterly, 32(4), pp. 646-653.

Jeffrey A. Brown (2011) Dangerous Curves: Action Heroines, Gender, Fetishism, and Popular Culture. first. Mississippi: Univ. Press of Mississippi.

Lapsley, D. K. and Stey, P. C. (2011). 'Id, ego, and superego', Encyclopedia of human behavior, pp. 1-9.

Misiroglu, G. and David A, R. (2004). The Superhero Book. Edited by G. Misiroglu and D. Roach. Los Angeles: Visible Ink Press.

Rose, G. (2016) Visual methodologies: An introduction to researching with visual materials. London: sage.

Rovin, J. (1985) The_Encyclopedia_of_Superheroes. New York: Facts On File Publications.

Setyanto, D. W., Soewarlan, S. and Tinarbuko, S. (2019). 'Reading the Message of Feminism in Wonder Woman Film', in Proceedings of the 1st Seminar and Workshop on Research Design, for Education, Social Science, Arts, and Humanities, SEWORD FRESSH 2019, April 27 2019, Surakarta, Central Java, Indonesia. Surakarta: Uiversitas Sebelas Maret.

Sobur, A. (2003). Semiotika Komunikasi. Bandung: Rosda.

Tinarbuko, S. (2019). 'Desain Komunikasi Visual : Berpikir Kreatif dan Berkarya Inovatif', in Internasional Seminnar On Innovation and Creativity Of Art (ISICA\#2). Surakarta.

Tong, R. (2009). Feminist Thought. 3rd edn, University of North Carolina, Charlotte. 3rd edn. Colorado: Westview. 